\title{
Phytochemical screening and evaluation of the antioxidant and anti-bacterial activity of Woundwort (Anthyllis vulneraria L.)
}

\author{
Manel Ouerfelli ${ }^{1,2}$ (D) Nesine Majdoub ${ }^{1} \cdot$ Jihen Aroussi $^{3} \cdot$ María Pilar Almajano $^{2}\left(\mathbb{0} \cdot\right.$ Leila Bettaieb Ben Kaâb $^{1}$
}

Received: 17 June 2021 / Revised: 28 July 2021 / Accepted: 31 July 2021 / Published online: 22 August 2021

(c) The Author(s) 2021

\begin{abstract}
For millennia, medicinal plants have been used to prevent and cure diseases. Up to now there is a growing interest in their use in several areas as conducted for Anthyllis in our investigation. Actually the present research aims to investigate the biochemical characterisation of a medicinal plant collected from Tunisia named Woundwort [Anthyllis vulneraria L. (Jones and Turrill 1933)] by determining the mineral content, phenolic compound contents and biological activities of its leaf and flower extracts. On the one hand, the results obtained showed that $A$. vulneraria accumulated minerals at different amounts with significant differences between leaves and flowers extracts. On the other hand, the data revealed that the hydroethanolic flower extract contained the highest content of total polyphenols, flavonoids and condensed tannin, as it exhibited the strongest antioxidant activity. The flower extract also showed better antibacterial effect than leaf extract. These results support the exploitation of active compounds extracted from the leaves and especially the flowers of A. vulneraria, which can provide new alternatives to the use of certain drugs, additives, among others, as they can be used as structure-activity models for the development of new products.
\end{abstract}

Keywords Biological activity $\cdot$ Medicinal plant $\cdot$ Minerals $\cdot$ Phenolic compounds

$\begin{array}{ll}\text { Abbreviations } \\ \mathrm{AlCl}_{3} & \text { Aluminium chloride } \\ \mathrm{ATCC} & \text { American Type Culture Collection } \\ \mathrm{EtOH} & \text { Ethanol } \\ \mathrm{FeCl}_{2} & \text { Iron(II) chloride } \\ \mathrm{H}_{2} \mathrm{O}_{2} & \text { Hydrogen peroxide } \\ \mathrm{MeOH} & \text { Methanol } \\ \text { UV-B } & \text { Ultraviolet }(280-315 \mathrm{~nm})\end{array}$

Manel Ouerfelli

manel.ouerfelli@upc.edu

1 Biology Department (BD), Faculty of Sciences of Tunis (FST), University of Tunis El-Manar (UTM), University Campus of Tunis El-Manar, 2092 Tunis, Tunisia

2 Chemical Engineering Department (DEQ), Escola Tècnica Superior d'Enginyeria Industrial de Barcelona (ETSEIB), Universitat Politècnica de Catalunya (UPC), Av, Diagonal 647, 08028 Barcelona, Spain

3 Research Unit "Plant Ecology", Department of Biology, Faculty of Sciences of Tunis, University of Tunis El Manar (UTM), University Campus of Tunis El-Manar, 2092 Tunis, Tunisia

\section{Introduction}

Anthyllis vulneraria [A. vulneraria (Jones and Turrill 1933)], commonly named "Woundwort" is a mediterranean medicinal plant that belongs to the Fabaceae family (Nartowska et al. 2001). The term "Anthyllis" comes from the Latin words "Anthos" and "ioulos", which mean "flower" and "downy", respectively (as are the undersides of leaf), while "vulneraria" in Latin is "vulnus", which means "injury" referring generally to wounds healing (Halabalaki et al. 2011). As its name suggests, A. vulneraria is a popular remedy for burns and skin rashes. In the traditional medicine, A. vulneraria flowers were used to heal wounds, low the high blood pressure, treat inflammation, vomiting, acne and purify the body by promoting the elimination of toxins (Nartowska et al. 2001). They were also used to heal mouth and throat pain, to limit hair loss and promote hair growth (Menković et al. 2011). In recent years, A. vulneraria has attracted the attention of researchers to quantify its phenolic compounds and prove its potential as a source of bioactive molecules with effective biological properties. Different environmental factors, including biotic (microbial invasion, insect pests and herbivores) and abiotic (cold and drought) factors stimulate the production of a wide variety 
of bioactive substances in plants to protect themselves (Yang et al. 2018) and which also play a crucial role in preventing and curing human diseases (Sales de Oliveira et al. 2020).

In response to these external changes, plants vary their chemical composition, which explains the qualitative and quantitative differences in their metabolites during a given season and, consequently, the variation in their pharmacological property (Yang et al. 2018). Antioxidant components, such as phenolic compounds are generally received by the human organism as food, drugs and supplements (Lushchak 2014). The antioxidant activity is one of the most important biological properties that characterises bioactive substances produced by plants (Stagos 2020). Plants rich in phenolic compounds have an important pharmacological potential because of their antioxidant activity that allows them to adsorb, neutralise and eliminate free radicals (Stagos 2020) and thus, to defend against some cancer, infections, inflammation, microorganisms and cardiovascular disorders (Pandey and Rizvi 2009; Ncube et al. 2012). Plants also have long been known by their antimicrobial property. For this aim, many scientists looking for new antimicrobial agents are paying particular attention to the plant kingdom (Gorlenko et al. 2020).

The main target of the present study was to quantify mineral content in powdered A. vulneraria leaves and flowers and to determine the phenolic compound contents, antioxidant activity and antibacterial property of the leaf and flower ethanol extracts. Hence, in addition to previous findings, this investigation gives further information about the nutritive value of $A$. vulneraria as dietary supplements rich in natural antioxidants and could be also a supportive data for using the specie as a new industrial crop in cosmetic, pharmaceutical and food industries.

\section{Material and methods}

Chemicals and reagents - Catechin, $\mathrm{EtOH}, \mathrm{FeCl}_{2}$, ferrozine, gallic acid, vanillin, ascorbic acid and quercetin were purchased from Sigma-Aldrich Chimie (S.Q.F, France). $\mathrm{AlCl}_{3}, \mathrm{H}_{2} \mathrm{O}_{2}$, phosphate buffer, nitric acid and perchloric acid were acquired from Loba Chemie Pvt. Ltd (Mumbai, India). Mueller Hinton agar and Penicillin-Streptomycin (Pen-Strep) were bought from Thermo-Fisher Scientific (Barcelona, Spain).

Plant sampling - Anthyllis vulneraria was collected at the flowering stage (beginning of April) from Zaghouan located in the North of the Tunisian ridge (latitude $36^{\circ}, 24 \mathrm{~min}$, $10 \mathrm{~s}$ North; longitude $10^{\circ}, 08 \mathrm{~min}, 34 \mathrm{~s}$ East). Once brought back to the laboratory, A. vulneraria leaves and flowers were allowed to dry in the shade at room temperature. The weight was measured every 2 days until a constant weight (dry weight) was obtained. Then, dry samples were ground into a fine powder and stored in amber glass bottles for further analysis.

Determination of mineral content - Mineral content was determined in powdered A. vulneraria leaves and flowers by hot mineralisation with nitric and perchloric acids (Larsson et al. 1998; Rezgui et al. 2017). After the complete evaporation of the mixture and obtaining a white haze dry residue, $20 \mathrm{~mL}$ of nitric acid (N7) were added. The determination of iron $(\mathrm{Fe})$, copper $(\mathrm{Cu})$ and zinc $(\mathrm{Zn})$ contents was carried out using an atomic absorption spectrophotometer (Varian SpectrAA 220FS, Canada), whereas potassium (K) and calcium (Ca) contents were determined using a photoelectric flame photometer (Model 410 Flame Photometer Range, Cambridge, United Kingdom). The results obtained are expressed as microgram per gram of Dry Weight $\left(\mu \mathrm{g} \mathrm{g}^{-1} \mathrm{DW}\right)$.

\section{Phenolic compound contents in $A$. vulneraria leaf and flower extracts -}

Extracts preparation. The preparation of $A$. vulneraria leaf and flower extracts was assessed using two different methods, including cold maceration extraction and ultrasound assisted extraction.

To perform the cold maceration extraction, $1 \mathrm{~g}$ of each dry sample was mixed with $10 \mathrm{~mL}$ of different concentrations of $\mathrm{EtOH}$ (absolute, 75\% and 50\%) and extracted during $24 \mathrm{~h}$ at $4{ }^{\circ} \mathrm{C}$ under stirring using a multi-position magnetic stirrer (Ovan, MM90E, Barcelona, Spain). Then, the extracts were centrifuged (Orto Alresa Mod. Consul, Ajlvir, Madrid, Spain) at $1500 \times g$ for $10 \mathrm{~min}$. The different supernatants were concentrated using a sample concentrator (Techne FSC496D sample concentrator, Madrid, Spain) under a jet of moderate nitrogen gas, then lyophilised using a freeze dryer (Unicryo MC2L, UniEquip Laborgerätebau \& Vertr. GmbH, Munich, Germany) for 2 days.

The ultrasound assisted extraction method also was carried out using different concentrations of EtOH. Shortly, $1 \mathrm{~g}$ from each powdered leaf and flower was mixed with $10 \mathrm{~mL}$ of $\mathrm{EtOH}$ at different concentrations (absolute, 75\% and 50\%). The different mixtures were stirred using a vortex (FALC Instruments, A121498, Italy) for $1 \mathrm{~min}$ and extracted in an ultrasonic bath (COXO Medical Instrument CO., LTD, DB4820, Medical World Company) for $15 \mathrm{~min}$ at $25^{\circ} \mathrm{C}$ at a frequency of $40 \mathrm{kHz}$ and a power of $100 \mathrm{~W}$. Then, the extracts were filtered with filter paper (Wattman no. 4) and the supernatants obtained were concentrated then lyophilised for 2 days.

Anthyllis vulneraria leaf and flower freeze-dried extracts were dissolved in absolute $\mathrm{EtOH}, 75 \%$-aqueous $\mathrm{EtOH}$ and $50 \%$-aqueous EtOH and stored in darkness at $4{ }^{\circ} \mathrm{C}$ until their use. 
Extraction yield. The final dry weight of each lyophilised extract was used to calculate the extraction yield according to the following formula:

$\mathrm{EY}(\%)=\frac{W_{1}}{W_{2}} \times 100$

where $W_{1}$ represents the weight of the dry extract after the lyophilisation and $W_{2}$ represents the weight of the dry ground plant material.

Total polyphenol content. Total polyphenol content (TPC) in the leaf and flower extracts of A. vulneraria was determined following the method described by Singleton et al. (1965) and reported by Segovia Gómez and Almajano Pablos (2016). The absorbance reading was recorded at $765 \mathrm{~nm}$ using a spectrophotometer (MAPADA spectrophotometer, $U V-1600$. Shanghai Mapada Instruments co., Ltd). The calibration curve was prepared with gallic acid at different concentrations ranging from 100 to $1700 \mu \mathrm{M}\left(R^{2}=0.992\right)$. The results of TPC are expressed as milligram of Gallic Acid Equivalent per gram of Dry Weight (mg GAE g $\left.{ }^{-1} \mathrm{DW}\right)$.

Total flavonoid content. Total flavonoid content (TFC) was determined using the $\mathrm{AlCl}_{3}$ colorimetric method as described by Skowyra et al. (2014). The absorbance was measured at $405 \mathrm{~nm}$, and the calibration curve was prepared with quercetin at increasing concentrations from 50 to $500 \mu \mathrm{M},\left(R^{2}=0.998\right)$. Results are expressed as milligram of Quercetin Equivalent per gram of Dry Weight (mg QE $\left.\mathrm{g}^{-1} \mathrm{DW}\right)$.

Condensed tannin content. Condensed tannin content (CTC) was determined by the vanillin method described by Julkunen-Tiitto (1985). The absorbance was measured at $550 \mathrm{~nm}$, and the calibration curve was prepared with catechin at different concentrations ranging from zero to $1000 \mu \mathrm{g} \mathrm{mL}{ }^{-1},\left(R^{2}=0.997\right)$. Results are expressed as milligram of Catechin Equivalent per gram of Dry Weight ( $\mathrm{mg}$ $\left.\mathrm{CE} \mathrm{g}^{-1} \mathrm{DW}\right)$.

\section{Antioxidant activity of $A$. vulneraria leaf and flower extracts -}

Total antioxidant capacity by phosphor-molybdenum method. Total antioxidant capacity (TAC) of A. vulneraria leaf and flower extracts was determined as reported by Zengin et al. (2015). The absorbance of the mixtures obtained was measured at $695 \mathrm{~nm}$. The calibration curve was prepared with ascorbic acid at different concentrations ranging from zero to $100 \mu \mathrm{g} \mathrm{mL}^{-1},\left(R^{2}=0.998\right)$ and the TAC results are expressed as milligram of Ascorbic Acid Equivalent per gram of Dry Weight (mg AAE g $\left.{ }^{-1} \mathrm{DW}\right)$.
Ferrous ion chelating assay. Ferrous ion chelating (FIC) assay was assessed following the method of Dinis et al. (1994). Shortly, $100 \mu \mathrm{L}$ of each diluted extract were mixed with $0.2 \mathrm{~mL}$ of $2 \mathrm{mM} \mathrm{FeCl}_{2}$. The reaction was initiated by the addition of $0.4 \mathrm{~mL}$ of $5 \mathrm{mM}$ ferrozine and the mixtures were adjusted to $4 \mathrm{~mL}$ with $\mathrm{EtOH}$. After shaking, the mixtures were incubated in the dark at room temperature for $10 \mathrm{~min}$. The absorbance of the extracts was measured at $562 \mathrm{~nm}$ and the percentage of $\mathrm{Fe}^{2+}$ chelating effect (FIC effect (\%)) was calculated as follows:

FIC effect $(\%)=\left(1-\frac{\mathrm{As}}{\mathrm{Ac}}\right) \times 100$

where Ac is the absorbance of the blank (containing $\mathrm{FeCl}_{2}$ ferrozine complex) and As is the absorbance of the extract.

Hydrogen peroxide scavenging assay. Hydrogen peroxide scavenging (HPS) assay was determined as described by Ruch et al. (1989). A solution of $43 \mathrm{mM} \mathrm{H}_{2} \mathrm{O}_{2}$ was prepared with phosphate buffer $(0.1 \mathrm{M}, \mathrm{pH}=7.4)$, then $100 \mu \mathrm{L}$ from each extract were mixed with $0.6 \mathrm{~mL}$ of $\mathrm{H}_{2} \mathrm{O}_{2}$ solution. The percentage of $\mathrm{H}_{2} \mathrm{O}_{2}$ scavenging effect (HPS effect (\%)) was calculated using the following formula:

HPS effect $(\%)=\left(1-\frac{\mathrm{As}}{\mathrm{Ac}}\right) \times 100$

where Ac is the absorbance of the blank (containing sodium phosphate buffer without $\mathrm{H}_{2} \mathrm{O}_{2}$ ) and As is the absorbance of the extract.

\section{Determination of antibacterial activity of $A$. vulneraria leaf and flower extracts -}

Bacterial strains tested. Six different microbial strains, causing infective and toxic food poisoning, were provided by the "Departament de Biologia, Sanitat i Medi Ambient" of the Universitat de Barcelona to be tested; including Staphylococcus aureus (ATCC 25923), Bacillus cereus (ATCC 11778), Listeria monocytogenes (ATCC 15,313), Micrococcus luteus (ATCC 4698), Escherichia coli (ATCC 25922) and Salmonella paratyphi (ATCC 9150).

Inhibitory zone assay (disc diffusion method). To perform the disc diffusion method, $15 \mathrm{~mL}$ of Mueller Hinton agar was inoculated with $200 \mu \mathrm{L}$ of bacterial suspension $\left(0.4 \times 10^{4} \mathrm{CFU} \mathrm{mL} \mathrm{mL}^{-1}\right)$ then kept in culture dishes until solidification. Oxford discs were placed in the inoculated plates and impregnated with each extract $\left(100 \mu \mathrm{g} \mathrm{mL}^{-1}\right)$, and then the plates were incubated at $30{ }^{\circ} \mathrm{C}$. The penicillin $\left(100 \mu \mathrm{g} \mathrm{mL}^{-1}\right)$ was used as a positive control, while the sterile EtOH 50\% was used as a negative control (Fan et al. 2019). The plates were read from the back against a dark 
background. The diameter of the zone inhibition measured in millimetre $(\mathrm{mm})$ correlates to the sensitivity of the strain to the extract.

Minimum inhibitory zones (MIC). The minimum inhibitory concentration (MIC) of the extracts (50\%-aqueous EtOH) was determined using the broth dilution method reported by Manandhar et al. (2019) with some modifications. Twofold serial dilutions of the antibiotic (penicillin) and the different extracts were prepared $(0.062,0.125,0.25,0.5$ and $1 \mathrm{mg} \mathrm{mL}^{-1}$ ), then $0.2 \mathrm{~mL}$ of the different bacterial suspensions were added to each test tube except the negative control (CTR-) and tubes were incubated for $24 \mathrm{~h}$ at $37^{\circ} \mathrm{C}$. The MIC was calculated following the formula described below:

$\operatorname{MIC}\left(\mathrm{mg} \mathrm{mL}^{-1}\right)=\frac{\mathrm{Lc}+\mathrm{Hc}}{2}$

where Lc represents the extract's lowest concentration inhibiting the growth of microbial strains and Hc represents the extract's highest concentration allowing the growth of microbial strains.

Statistical analysis - For all the parameters studied below, extracts were analysed in triplicate $(n=3)$. Statistical analysis was performed using the one-way analysis of variance (ANOVA) in Minitab software (Version 18, München, Germany), where Tukey test was used at a significance level of $p<0.05$.

\section{Results}

Mineral content - Minerals content was determined in powdered A. vulneraria leaves and flowers and the results obtained are presented in Table 1.

The results obtained showed that powdered A. vulneraria leaves and flowers accumulated important minerals contents with significant differences among extracts $(p<0.05)$. Flowers contained higher contents of $\mathrm{Ca}, \mathrm{Cu}$ and $\mathrm{Zn}$ than leaves extract with significant differences estimated at 17.5, 37.13 and $21.79 \%$, respectively. Additionally, Fe content in flowers was two folds higher than $\mathrm{Fe}$ content determined in leaves extract. Contrariwise, A. vulneraria leaves contained the highest $\mathrm{K}$ content estimated at $12,320 \mu \mathrm{g} \mathrm{mg}^{-1} \mathrm{DW}$, while flowers contained only $9462 \mu \mathrm{g} \mathrm{mg}^{-1} \mathrm{DW}$.

There are various reports in literature about minerals amounts analyses in different species, meanwhile there is no data concerning the mineral composition of Tunisian $A$. vulneraria, which prompt us to conduct these analyses. For instance, Butkut et al. (2018) determined the mineral composition of two Astragalus species from the Fabaceae family, including Astragalus glycyphyllos and Astragalus cicer, and reported that $\mathrm{K}, \mathrm{Ca}, \mathrm{Zn}$ and $\mathrm{Fe}$ contents in the leaves of Astragalus glycyphyllos were lower than contents in leaves of $A$. vulneraria with values estimated at 89.7, 22.2, 27 and $226.6 \mu \mathrm{g} \mathrm{mg}^{-1} \mathrm{DW}$, respectively, and were lower in flowers with contents equal to 78.8, 29.4, 47.6 and $141 \mu \mathrm{g} \mathrm{mg}^{-1} \mathrm{DW}$, respectively. Mineral contents were also lower in Astragalus cicer leaves and flowers compared with mineral contents in A. vulneraria leaves and flowers.

\section{Phenolic compound content in A. vulneraria leaf and flower extracts -}

Extraction yield of extracts. The extraction solvent and method efficiency to extract phenolic compounds from $A$. vulneraria leaf and flower extracts was determined and the results are represented in Table 2.

Extraction yield values were significantly different $(p<0.05)$ depending on the extraction method and the solvent concentration used for the extraction. From the perspective of the extraction method, the highest extraction yields were found in the leaf and flower extracts extracted using ultrasound assisted extraction method, which were 1.5-, 2.4- and 2.5-folds higher in leaf extract and 1.5, 1.8- and 1.4- in flower extract compared with leaf and flower extracts extracted using cold maceration method when extracted with absolute $\mathrm{EtOH}, 75 \%$ and 50\%-aqueous EtOH, respectively.

The results depicted in Table 2 also revealed a significant influence of the extraction power of the solvent on the yield. Hydroethanolic solvent was the most suitable for better extraction of phytochemical components and flower extract presented the highest extraction yield. The leaves and flowers extracted with 50\%-aqueous EtOH showed better extraction yield estimated at $58.15 \%$ and $66.19 \%$ when extracted by ultrasound assisted extraction method and $22.72 \%$ and $46.14 \%$ when extracted by cold maceration
Table 1 Minerals content in powdered A. vulneraria leaves and flowers

\begin{tabular}{lcclll}
\hline \multicolumn{5}{l}{ Minerals content $\left(\mu \mathrm{g} \mathrm{mg}^{-1} \mathrm{DW}\right)$} \\
\cline { 2 - 6 } & $\mathrm{K}$ & $\mathrm{Ca}$ & $\mathrm{Cu}$ & $\mathrm{Fe}$ & $\mathrm{Zn}$ \\
\hline Leaves & $12,320 \pm 35.2^{\mathrm{b}}$ & $16,320 \pm 36.9^{\mathrm{a}}$ & $51.82 \pm 1^{\mathrm{a}}$ & $792.27 \pm 3.1^{\mathrm{a}}$ & $155.81 \pm 1.3^{\mathrm{a}}$ \\
Flowers & $9462 \pm 23.2^{\mathrm{a}}$ & $19,190 \pm 11.3^{\mathrm{b}}$ & $71.06 \pm 0.6^{\mathrm{b}}$ & $1546.66 \pm 26.1^{\mathrm{b}}$ & $199.24 \pm 3^{\mathrm{b}}$ \\
\hline
\end{tabular}

Results represent the mean of three replicates $(n=3)$ and are expressed as mean value \pm SD. Different letters in each column indicate significant differences between extracts at $p<0.05$ 
Table 2 Extraction yield of A. vulneraria leaf and flower extracts

\begin{tabular}{|c|c|c|c|c|c|c|}
\hline \multirow[t]{3}{*}{ Extract } & \multicolumn{6}{|c|}{ Extraction yield (\%) } \\
\hline & \multicolumn{3}{|c|}{ Maceration extraction } & \multicolumn{3}{|c|}{ Ultrasound assisted extraction } \\
\hline & EtOH & $75 \% \mathrm{EtOH}$ & $50 \% \mathrm{EtOH}$ & $\mathrm{EtOH}$ & $75 \% \mathrm{EtOH}$ & $50 \% \mathrm{EtOH}$ \\
\hline Leaf & $8.61^{\mathrm{b}}$ & $14.21^{\mathrm{b}}$ & $22.72^{\mathrm{b}}$ & $12.72^{\mathrm{b}}$ & $34.41^{\mathrm{b}}$ & $58.15^{\mathrm{b}}$ \\
\hline Flower & $16.48^{\mathrm{a}}$ & $27.12^{\mathrm{a}}$ & $46.14^{\mathrm{a}}$ & $24.98^{\mathrm{a}}$ & $49.26^{\mathrm{a}}$ & $66.19^{\mathrm{a}}$ \\
\hline
\end{tabular}

Results represent the mean of three replicates $(n=3)$ and are expressed as mean value \pm SD. Different lowercase letters indicate significant differences between extracts at $p<0.05$

\begin{tabular}{lcll}
\hline 50\%-EtOH extract & TPC $\left(\mathrm{mg} \mathrm{GAE} \mathrm{g}^{-1} \mathrm{DW}\right)$ & TFC $\left(\mathrm{mg} \mathrm{QE} \mathrm{g}^{-1} \mathrm{DW}\right)$ & TCTC $\left(\mathrm{mg} \mathrm{CE} \mathrm{g}^{-1} \mathrm{DW}\right)$ \\
\hline Leaf & $93.27 \pm 0.21^{\mathrm{b}}$ & $37.88 \pm 0.18^{\mathrm{b}}$ & $22.72 \pm 0.11^{\mathrm{b}}$ \\
Flower & $147.77 \pm 0.11^{\mathrm{a}}$ & $48.83 \pm 0.37^{\mathrm{a}}$ & $24.24 \pm 0.14^{\mathrm{a}}$ \\
\hline
\end{tabular}

Results represent the mean of three replicates $(n=3)$ and are expressed as mean value \pm SD. Different lowercase letters indicate significant differences between extracts at $p<0.05$
Table 3 Phenolic compounds contents of A. vulneraria leaf and flower extracts
Table 4 Antioxidant activity of A. vulneraria leaf and flower extracts

\begin{tabular}{lcl}
\hline & Leaf & Flower \\
\hline TAC (mg AAE g & \\
FIC (\%) & $219.7 \pm 0.02^{\mathrm{b}}$ & $293.3 \pm 0.01^{\mathrm{a}}$ \\
HPS (\%) & $48 \pm 0.03^{\mathrm{b}}$ & $65 \pm 0.06^{\mathrm{a}}$ \\
\hline
\end{tabular}

Results represent the mean of three replicates $(n=3)$ and are expressed as mean value \pm SD. Different lowercase letters indicate significant differences between extracts at $p<0.05$

\section{Spectrophotometric determination of phenolic com-} pounds. The different phenolic compounds contents determined spectrophotometrically are represented in Table 3.

The phenolic compound contents found in A. vulneraria leaf and flower extracts varied among extracts with significant differences at $p<0.05$. The highest phenolic compound contents were found in the flower extract and were estimated at $147.77 \mathrm{mg} \mathrm{GAE} \mathrm{g}^{-1} \mathrm{DW}$ for TPC, $48.83 \mathrm{mg} \mathrm{QE} \mathrm{g}^{-1} \mathrm{DW}$ for TFC and $24.24 \mathrm{mg} \mathrm{CE} \mathrm{g}^{-1} \mathrm{DW}$ for TCTC, while the leaf extract contained TPC and TFC 1.6- and 1.3-folds, respectively, lower and a TCTC broadly similar to that determined in the flower extract.

Quantitative and qualitative variation of phenolic compound contents in A. vulneraria extracts was observed in several recent studies. For example, Moradi et al. (2018) determined TPC and TFC in A. vulneraria leaves collected from the south west city of Iran and extracted in EtOH. The results obtained were two folds higher than contents found in the present study. Csepregi et al. (2016) measured also TPC, TFC and CTC in A. vulneraria extract and found contents very lower than contents found in our study estimated at $6.8,1.7$ and $4.5 \mathrm{~g} \mathrm{GAE} \mathrm{g}^{-1} \mathrm{DW}$, respectively. Such trend has been previously studied on Fabaceae family plants. For instance, Al-Dabbagh et al. (2018) determined TPC and TFC in the leaves extract of Trigonella foenum-graecum and Cassia acutifolia extracted with $70 \% \mathrm{EtOH}$ and found
TPC lower than A. vulneraria estimated at 9.7 and $10.5 \mathrm{mg}$ GAE $\mathrm{g}^{-1} \mathrm{DW}$, respectively, and TFC almost similar to TFC found in our study estimated at 14.6 and $20.8 \mathrm{mg} \mathrm{QE} \mathrm{g}^{-1}$, respectively. Chen et al. (2018) quantified also TPC and TFC in the flowers of Pueraria lobate and Sophora japonica and reported TPC of 23.99 and $81.17 \mathrm{mg} \mathrm{GAE} \mathrm{g}^{-1} \mathrm{DW}$, respectively, and TFC estimated at 14.59 and $42.88 \mathrm{mg} \mathrm{RE} \mathrm{g}^{-1}$ DW, respectively.

Antioxidant activity - The evaluation of the antioxidant activity of $A$. vulneraria leaf and flower extracts was carried out in vitro by different analytical methods and the results are in Table 4.

Radical scavenging activity was significantly higher in A. vulneraria flower extract than in leaf extract $(p<0.05)$. On the one hand, the flower extract showed a significantly higher TAC $(p<0.05)$ compared to the leaf extract estimated at $293.3 \mathrm{mg} \mathrm{AAE} \mathrm{g}^{-1} \mathrm{DW}$. Furthermore, the flower extract of A. vulneraria exhibited as well FIC and HPS activities 1.3- and 1.4-folds higher than the leaf extract, respectively.

Antioxidant activity of medicinal plants belonging to different families was determined in previous studies. For example, antioxidant activity of medicinal plants belonging to different families was determined in previous studies. For 
example, Sharma and Vig (2014) found better TAC values in Parkinsonia aculeate extract than TAC obtained in the present study estimated at $360 \mathrm{mg} \mathrm{g}^{-1}$ of extract. Osman et al. (2018) also determined TAC in Dialium indum extract and found values ranging between 104.52 and $1515.79 \mu \mathrm{mol}$ TE/g Dry Extract.

Based on Tables 3 and 4 results, it can be suggested that antioxidant activities of extracts are linked to their polyphenol contents, which can support the hypothesis of a positive correlation between the effectiveness of extracts antioxidant capacities and their phenolic amounts as submitted by supportive studies of Pisoschi and Pop (2015) and Gabriela et al. (2016).

\section{Antibacterial activity screening -}

Inhibitory zone. The sensitivity of bacterial strains against $A$. vulneraria leaf and flower extracts was determined after $48 \mathrm{~h}$ of incubation at $37^{\circ} \mathrm{C}$. The area developed around the discs

Table 5 Diameters of the inhibitory zones (mm) developed around discs treated with $A$. vulneraria leaf and flower extracts $\left(100 \mu \mathrm{gL}^{-1}\right)$

\begin{tabular}{|c|c|c|c|c|c|}
\hline & \multicolumn{5}{|c|}{ Inhibitory zone (mm) } \\
\hline & $\begin{array}{l}\text { Microorgan- } \\
\text { ism }\end{array}$ & $50 \% \mathrm{EtOH}$ & Penicillin & Leaf & Flower \\
\hline \multirow[t]{4}{*}{ Gram +} & S. aureus & NS & $24 \pm 1.8^{\mathrm{c}}$ & $10 \pm 0.6^{\mathrm{a}}$ & $18 \pm 1.4^{\mathrm{b}}$ \\
\hline & M. luteus & NS & $19 \pm 1.2^{\mathrm{c}}$ & $12 \pm 0.2^{\mathrm{a}}$ & $15 \pm 0.5^{b}$ \\
\hline & $\begin{array}{l}\text { L. monocy- } \\
\text { togenes }\end{array}$ & NS & $15 \pm 0.9^{b}$ & $10 \pm 0.3^{\mathrm{a}}$ & $11 \pm 0.6^{\mathrm{a}}$ \\
\hline & B. cereus & NS & $10 \pm 0.3^{\mathrm{a}}$ & $9 \pm 0.2^{\mathrm{a}}$ & $14 \pm 0.8^{b}$ \\
\hline \multirow[t]{2}{*}{ Gram - } & S. paratyphi & NS & $30 \pm 1.6^{\mathrm{b}}$ & NS & $4 \pm 1.5^{\mathrm{a}}$ \\
\hline & E. coli & NS & $27 \pm 1.8^{\mathrm{b}}$ & $5 \pm 1^{\mathrm{a}}$ & NS \\
\hline
\end{tabular}

Results are means of three different experiments $(n=3)$. Means in the same row with different letters are significantly different $(p<0.05)$. Penicillin $\left(100 \mu \mathrm{g} \mathrm{mL}^{-1}\right)$ was used as a positive control. Sterile 50\%-aqueous EtOH was used as negative control. No inhibition zone is indicated by NS (Not Sensitive) treated with extracts was measured and the results obtained are represented in Table 5.

According to the results obtained, the leaf and flower extracts of $A$. vulneraria $\left(100 \mu \mathrm{g} \mathrm{mL}^{-1}\right)$ showed a significant inhibitory effect against the bacteria growth $(p<0.05)$. The flower extract showed better antibacterial activity than the leaf extract. The best antibacterial activity of the flower extract was against $S$. aureus strain with an inhibition zone estimated at $18 \mathrm{~mm}$, while the best antibacterial activity of the leaf extract was observed against $M$. luteus strain with an inhibitory zone of $12 \mathrm{~mm}$. However, the leaf and flower extracts did not show any antimicrobial activity against $S$. paratyphi and $E$. coli strains, respectively, as compared with the penicillin $\left(100 \mu \mathrm{g} \mathrm{mL}^{-1}\right)$, which showed inhibition zones of 30 and $27 \mathrm{~mm}$, respectively.

Minimum inhibitory concentration. The minimum inhibitory concentration (MIC) assay was assessed for only the bacterial strains that showed a sensitivity to A. vulneraria leaf and flower extracts $\left(100 \mu \mathrm{g} \mathrm{mL} \mathrm{m}^{-1}\right)$ in the disc diffusion method previously performed and the results obtained are in Table 6 .

Table 6 shows the turbidity of the penicillin, A. vulneraria leaf and flower inoculations, and positive $\left(\mathrm{CTR}^{+}\right)$and negative $\left(\mathrm{CTR}^{-}\right)$controls after $24 \mathrm{~h}$ of incubation. The $\mathrm{CTR}^{+}$ containing the broth nutrient, bacterial culture and antibiotic or A. vulneraria extracts showed turbidity (bacterial growth) after the $24 \mathrm{~h}$ of incubation and was used to test the growing ability of the medium, while the $\mathrm{CTR}^{-}$containing only the broth nutrient and the antibiotic or A. vulneraria extract did not show turbidity (no bacterial growth) after the $24 \mathrm{~h}$ of incubation and was used to test the sterility of the medium and equipment.

Bacterial growth (indicated by the presence of turbidity in the inoculum) was observed for all the bacterial strains tested at the concentrations of penicillin 0.062 and $0.125 \mathrm{mg} \mathrm{mL}^{-1}$ and only for L. monocytogenes and E. coli at the penicillin concentration $0.25 \mathrm{mg} \mathrm{mL}^{-1}$. In one hand, the penicillin at 0.5 and $1 \mathrm{mg} \mathrm{mL}^{-1}$ inhibited totally the growth of all the bacterial strains. Likewise, A. vulneraria leaf extract at $0.062,0.125$ and $0.25 \mathrm{mg} \mathrm{mL}^{-1}$ was not enough to inhibit

Table 6 Turbidity of the Penicillin, A. vulneraria leaf and flower inoculations after $24 \mathrm{~h}$ of incubation at $37{ }^{\circ} \mathrm{C}$

\begin{tabular}{|c|c|c|c|c|c|c|c|c|c|c|c|c|c|c|c|c|c|}
\hline \multirow[t]{2}{*}{$\mathrm{Cc}\left(\mathrm{mg} \mathrm{mL}^{-1}\right)$} & \multicolumn{5}{|c|}{ Penicillin } & \multicolumn{5}{|c|}{ A. vulneraria leaf extract } & \multicolumn{5}{|c|}{ A. vulneraria flower extract } & \multirow[t]{2}{*}{$\mathrm{CTR}+$} & \multirow[t]{2}{*}{ CTR - } \\
\hline & 0.062 & 0.125 & 0.25 & 0.5 & 1 & 0.062 & 0.125 & 0.25 & 0.5 & 1 & 0.062 & 0.125 & 0.25 & 0.5 & 1 & & \\
\hline S. aureus & + & + & - & - & - & + & + & + & - & - & + & + & - & - & - & + & - \\
\hline M. luteus & + & + & - & - & - & + & + & - & - & - & + & + & - & - & - & + & - \\
\hline L. monocytogenes & + & + & + & - & - & + & + & + & - & - & + & + & - & - & - & + & - \\
\hline B. cereus & + & + & - & - & - & + & + & + & - & - & + & + & - & - & - & + & - \\
\hline S. paratyphi & + & + & - & - & - & NT & & + & + & - & - & + & - & & & & \\
\hline E. coli & + & + & + & - & - & + & + & + & + & + & NT & + & - & & & & \\
\hline
\end{tabular}

(+) Turbidity indicating bacterial growth, (-) no turbidity indicating no bacterial growth and NT indicates microbial strain not tested 
the growth of all the bacterial strains, except for M. luteus, which showed resistant at $0.25 \mathrm{mg} \mathrm{mL}^{-1}$. No bacterial growth was observed at 0.5 and $1 \mathrm{mg} \mathrm{mL}^{-1}$ of $A$. vulneraria leaf extract, except for E. coli. In the other hand, A. vulneraria flower extract showed better antimicrobial activity than the penicillin and A. vulneraria leaves extract by inhibiting the growth of all the bacterial strains without exception at $0.25 \mathrm{mg} \mathrm{mL}^{-1}$.

Based on results of Table 6, MIC of the different extracts tested against the different bacterial strains were calculated and the results obtained are represented in Table 7.

Anthyllis vulneraria flower extract was considered to have better antibacterial activity than penicillin and leaf extract. The flower extract of A. vulneraria had the lowest MIC values equal to $0.625 \mathrm{mg} \mathrm{mL}^{-1}$ to inhibit the growth of all the bacterial strains tested compared with the penicillin that showed similar results except for L. monocytogenes and E. coli, which showed sensitivity at a MIC value of $0.75 \mathrm{mg} \mathrm{mL}^{-1}$. The leaves of A. vulneraria presented the lowest antimicrobial effect with MIC values higher than those recorded in the penicillin and A. vulneraria flowers inoculums estimated at $0.75 \mathrm{mg} \mathrm{mL}^{-1}$ against $S$. aureus, $L$. monocytogenes and B. cereus strains, except for $M$. luteus strain $\left(0.625 \mathrm{mg} \mathrm{mL}^{-1}\right)$ and E. coli where MIC value was higher than the highest concentration of the penicillin used $\left(\geq 1 \mathrm{mg} \mathrm{mL}^{-1}\right)$.

\section{Discussion}

Plants frequently accumulate metabolites, mainly phenolic compounds, which represent an important source of molecules that can be used by humans for different purposes. These phenolic compounds, such as phenolic acids, flavonoids, stilbenes and lignans, etc., correspond to a very wide range of chemical structures and are characterised by an unequal qualitative and quantitative distribution. After

Table 7 MIC values of the penicillin and A. vulneraria extracts against the different bacterial strains

\begin{tabular}{llll}
\hline & \multicolumn{2}{l}{$\mathrm{MIC}\left(\mathrm{mg} \mathrm{mL}^{-1}\right)$} & \\
\cline { 2 - 4 } & Penicillin & Leaf & Flower \\
\hline S. aureus & 0.625 & 0.75 & 0.625 \\
M. luteus & 0.625 & 0.625 & 0.625 \\
L. mmonocytogenes & 0.75 & 0.75 & 0.625 \\
B. cereus & 0.625 & 0.75 & 0.625 \\
S. paratyphi & 0.625 & $\mathrm{NT}$ & 0.625 \\
E. coli & 0.75 & $*$ & $\mathrm{NT}$ \\
\hline
\end{tabular}

* MIC is higher than the highest concentration of the antibiotic/extract in the first tube, NT indicates microbial strain not tested several years of research, different studies have shown the biological virtues of these compounds in different fields (Lin et al. 2016; Cosme et al. 2020). The main property of these compounds is their antioxidant activity, which consists in neutralising free radicals that are harmful for living organisms. Beyond the antioxidant property, phenolic compounds are characterised by their powerful antimicrobial property as well as many other biological activities (Wang et al. 2009). In the present work, A. vulneraria was studied since it was widely used in folk medicine for centuries owing to its varied chemical composition and active ingredients. Several previous investigations have focused on the biological properties of A. vulneraria have demonstrated its efficiency to prevent and treat different diseases. For instance, the consumption of A. vulneraria aerial part as an infusion has been shown to treat vomiting, diabetes, and stomach disorder (Csepregi et al. 2020). The aerial part also have been used to treat wounds and swelling by direct application (Godevac et al. 2008). Moreover, A. vulneraria leaves have been proven to be effective in inhibiting human herpes-virus and poliovirus (Suganda et al. 1983). The flowers as well have a potent therapeutic efficacy against wounds, high blood pressure, heart failure, portal hypertension, vomiting, inflammation, acne and throat pain (Nartowska et al. 2001). The objectives of the present research work were to quantify the mineral content in A. vulneraria leaves and flowers, determine their phenolic compound contents and evaluate their antioxidant and antibacterial properties.

Essential minerals, like $\mathrm{K}$ and $\mathrm{Ca}$, and trace elements, like $\mathrm{Fe}, \mathrm{Zn}$, and $\mathrm{Cu}$, are important for plants metabolic processes, such as chlorophyll synthesis, respiration, as well as protein structure and function (Majdoub et al. 2017) and the consumption of plants rich in minerals is associated with numerous health benefits (Ryan-harshman and Aldoori 2005). Plants absorb minerals from the soil with their roots in varying amounts. This quantitative and qualitative absorption of minerals is influenced by environmental factors, such as the nature of the soil, aeration and temperature (Pallardy 2007). Each mineral nutrient plays a specific role in the development of the plant, for this reason some plants adopt different strategies to avoid the consequences related to the deficiency or excess of minerals and to cope with toxic heavy metals leading to serious physiological disorders (Rouached and Tran 2015). Several researchers showed that some Fabaceae species can tolerate high concentrations of heavy metals in the soil, such as $\mathrm{Cu}$ and $\mathrm{Zn}$ (Sujkowska-Rybkowska et al. 2020). In addition, owing to their ability to establish symbiotic association with nitrogen-fixing bacteria (nodulated rhizobia), Fabaceae species are capable to grow in metal contaminated sites (Ma et al. 2011; Karthik et al. 2017). Furthermore, Neubauer et al. (2000) reported that the root 
exudates resulting from the rhizobium-legume symbiosis in Fabaceae plants can also immobilise metal ions and reduce their harmful effects on plants when they are present in very high contents. Seeing their high adaptability to sites contaminated with heavy metals, Fabaceae species like A. vulneraria are applied in re-vegetation and phyto-stabilisation of mine tailings in Europe and northern Africa (Mohamad et al. 2017; Fagorzi et al. 2018; Sujkowska-Rybkowska and Ważny 2018), which can explain the high levels of $\mathrm{Cu}$ and $\mathrm{Zn}$ found in the leaves and flowers of $A$. vulneraria. The richness of medicinal and edible plants in minerals confers them interesting biological properties provided when they are consumed as food or administered as drugs (Karppanen 1991). For instance, trace elements, such as $\mathrm{Cu}$, Manganese (Mn), Selenium ( $\mathrm{Se}$ ), $\mathrm{Fe}$ and $\mathrm{Zn}$, are indispensable co-factors for metabolic reactions of antioxidant enzymes like SOD, CAT and GPx to protect the human body from radicals (Leung 1998). Moreover, several researches demonstrated the anti-inflammatory property of the $\mathrm{Zn}$ and its ability to decrease oxidative stress biomarkers (Prasad 2014). An investigation carried out by Roughead et al. (1999) confirmed as well the antioxidant activity of $\mathrm{Fe}$ and its capacity to decrease risk of heart disease and cancer.

The phenolic content of the leaf and flower extracts of A. vulneraria was determined as well. EtOH solvent was chosen to extract phenolic compounds since it is considered one of the most powerful pure natural solvents that does not present a danger for human consumption. In addition, EtOH is labelled by the Food and Drug Administration (FDA) as Generally Recognised As Safe (GRAS) food substance products (Alzeer and Abou Hadeed 2016), hence the possibility of its safe use in pharmaceutical, food and cosmetic products without fear of intoxication. The results obtained showed that, for A. vulneraria, the best extraction yield value and the highest phenolics contents were observed in the flowers extracted with $50 \%$-aqueous EtOH by ultrasound assisted extraction method. Being such an efficient and widely used extraction method on the industrial scale, the ultrasound assisted extraction method saves time as the chemical compounds, such as carotenoids and polyphenols, etc., diffuse more rapidly into the extraction medium, while producing high quality extracts that can be used for foods, supplements and pharmaceutical products (Safdar et al. 2017; Deng et al. 2017; Osorio-Tobón 2020). Moreover, Do et al. (2014) showed that increasing the water concentration in $\mathrm{EtOH}$ solvent improves the extraction efficiency and facilitates the extraction of chemical compounds that are soluble in both inorganic and organic solvents (Khaw et al. 2017) and thus, the extraction of the maximum contents of phenolic compounds. The results obtained also showed a significant difference $(p<0.05)$ in phenolics contents among the different extracts. The variability in phenolic compound contents observed in the different plant's parts may be due to biological (vegetative stage), environmental (climate) and technical (methods and extraction solvents polarity) factors (Ksouri et al. 2008; Sampaio et al. 2011; Liu et al. 2016). In our investigation, the estimated phenolic compounds varied significantly with respect to the used plant part and the extraction method and solvent, which is in line with the findings of Zengin et al. (2015) and Villasante et al. (2019). Researches about phenolic compounds, in particular flavonoids, seem to be very advanced by reason of their various physiological properties, such as anti-allergic, anti-inflammatory, antimicrobial, antiviral, antibacterial, anti-carcinogenic, antithrombotic, cardio-protective and vasodilator activities (Generali et al. 2019). The beneficial effects of polyphenols are of a particular interest in pharmaceutical, cosmetic and food industry. According to several researches that studied the positive impact of polyphenol consumption on health and prevention of diseases, manufacturers are now marketing polyphenol-enriched foods and dietary supplements (Martin and Apple 2009). In addition, their antioxidant activity ensures better preservation of cosmetic and food products by preventing lipid peroxidation (Chang and Kim 2018). In cosmetic industry, phenolic compounds are added in cosmetic products owing to their well-recognised properties, such as antioxidant, anti-inflammatory, antimicrobial, antimutagens and anti-aging activities, as well as their emollients, humectant, wound healing, protective agents against UV-B damage, and reducing skin discoloration effects (Halla et al. 2018).

Over the few last decades, several different analytical methods have been developed and improved in order to measure the antioxidant activity of plant's extracts (Cornelli 2009). In the present work, the antioxidant activity of A. vulneraria extracts was assessed by different analytical methods, including TAC, FIC and HPS assays and the results obtained showed as well a significant difference $(p<0.05)$ in antiradical assays among the different extracts. The results followed the same trend as the phenolics contents and showed that, for A. vulneraria, the strongest radical scavenging activities were exhibited by the flowers extracted with $50 \%$-aqueous EtOH by ultrasound assisted extraction method. The significant difference observed among the values obtained by the different antiradical methods can be explained by the type of the methods and their chemical backgrounds (Lahue 1981; Apak et al. 2016).

In addition to their antioxidant activity, $A$. vulneraria leaf and flower extracts showed potent antibacterial activity. Foodborne infections caused by bacteria or their toxins, viruses or parasites or unconventional agents are considered one of the serious problems that threaten food industries and consumer's health. A strong correlation between phenolic compounds and antibacterial activity has been found to be 
significant in several recent studies (Maddox et al. 2010). In this research work, the antimicrobial analysis revealed that A. vulneraria leaf extract inhibited the growth of Staphylococcus aureus, Micrococcus luteus, Listeria monocytogenes, Bacillus cereus and Escherichia coli, but it did not show any antimicrobial activity against Salmonella paratyphi strain, while flower extract had an antimicrobial activity against all the bacterial strains tested except Escherichia coli strain. Previous studies showed that the antibacterial activity of plant's extracts depended mainly on their richness on polyphenol contents (Maddox et al. 2010). Polyphenols are endowed with significant antimicrobial activity. Their activity is probably due to their ability to complex with extracellular proteins and makes complexes with the bacterial cell membrane. One of the most important functions of phenolic compounds, mainly flavonoids, is their role in protective effect against microbial invasion. This involves their accumulation as phytoalexins in response to microbial attack. Due to their ability to inhibit photogenic spore germination in plants, they have also been proposed for use against fungal pathogens in humans (Cho and Lee 2015). Several studies reported the regular presence of antimicrobial activity in flavonoids. The majority of flavonoids, recognised as antifungal constituents, are isoflavonoids, flavones and flavanones (Qiu et al. 2014). Additionally, the absence of antimicrobial activity in leaves extract against $S$. paratyphi strain and in flowers extract against $E$. coli strain could be explained by the fact that those strains developed resistance mechanisms or the concentration of A. vulneraria extracts are not high enough to inhibit bacterial growth.

To summarise, the results obtained in the present study suggest that the richness of $A$. vulneraria in minerals and phenolic compounds and their unequal distribution in its leaf and flower extracts confer it antioxidant and antibacterial activity and supported its involvement in pharmaceutical, cosmetic and food products to enhance their quality while insuring consumer health.

Acknowledgements This work was funded by the Ministry of High Education and Scientific Research, Tunisia. The authors appreciate the collaboration and the material support of Escola Tècnica Superior d'Enginyeria Industrial de Barcelona (ETSEIB). Authors also are grateful to Mr Mounir Kasri from the Tunisian National Institute of Agronomic Research (INRAT) for identifying the plant investigated (Anthyllis vulneraria L.) and to the antimicrobial department in the Universitat de Barcelona (UB) for providing bacterial strains.

Author's contributions MO contributed to the study conception, design, conceptualisation, methodology, software, investigation and data curation. The first draft of the manuscript was written by MO. Material preparation, data collection and analysis were performed by MO, NM, JA and MPA. LBK and MPA supervised and validated the work. All authors commented on previous versions of the manuscript, and read and approved the final manuscript.
Funding Open Access funding provided thanks to the CRUE-CSIC agreement with Springer Nature.

\section{Declarations}

Conflict of interest The authors declare that they have no conflict of interest.

Open Access This article is licensed under a Creative Commons Attribution 4.0 International License, which permits use, sharing, adaptation, distribution and reproduction in any medium or format, as long as you give appropriate credit to the original author(s) and the source, provide a link to the Creative Commons licence, and indicate if changes were made. The images or other third party material in this article are included in the article's Creative Commons licence, unless indicated otherwise in a credit line to the material. If material is not included in the article's Creative Commons licence and your intended use is not permitted by statutory regulation or exceeds the permitted use, you will need to obtain permission directly from the copyright holder. To view a copy of this licence, visit http://creativecommons.org/licenses/by/4.0/.

\section{References}

Al-Dabbagh B, Elhaty IA, Al Hrout A et al (2018) Antioxidant and anticancer activities of Trigonella foenum-graecum, Cassia acutifolia and Rhazya stricta. BMC Complement Altern Med 18:1-12. https://doi.org/10.1186/s12906-018-2285-7

Alzeer J, Abou Hadeed K (2016) Ethanol and its Halal status in food industries. Trends Food Sci Technol 58:14-20. https://doi.org/10. 1016/j.tifs.2016.10.018

Apak R, Özyürek M, Güçlü K, Çapanołlu E (2016) Antioxidant activity/capacity measurement. 1. Classification, physicochemical principles, mechanisms, and electron transfer (ET)-based assays. J Agric Food Chem 64:997-1027. https://doi.org/10.1021/acs. jafc.5b04739

Butkut B, Dagilyt A, Benetis R et al (2018) Mineral and phytochemical profiles and antioxidant activity of herbal material from two temperate Astragalus species. BioMed Res Int. https://doi.org/10. $1155 / 2018 / 6318630$

Chang E, Kim CY (2018) Lipid peroxidation and antioxidant activities of the aqueous rhizome extract of Rheum officinale Baillon. J Food Qual. https://doi.org/10.1155/2018/5258276

Chen GL, Chen SG, Xiao Y, Fu NL (2018) Antioxidant capacities and total phenolic contents of 30 flowers. Ind Crops Prod 111:430 445. https://doi.org/10.1016/j.indcrop.2017.10.051

Cho MH, Lee SW (2015) Phenolic phytoalexins in rice: biological functions and biosynthesis. Int J Mol Sci 16:29120-29133. https:// doi.org/10.3390/ijms161226152

Cornelli U (2009) Antioxidant use in nutraceuticals. Clin Dermatol 27:175-194. https://doi.org/10.1016/j.clindermatol.2008.01.010

Cosme P, Rodríguez AB, Espino J, Garrido M (2020) Plant phenolics: bioavailability as a key determinant of their potential healthpromoting applications. Antioxidants 9:1-20. https://doi.org/10. 3390/antiox9121263

Csepregi R, Bencsik T, Papp N (2016) Examination of secondary metabolites and antioxidant capacity of Anthyllis vulneraria, Fuchsia sp., Galium mollugo and Veronica beccabunga. Acta Biol Hung 67:442-446. https://doi.org/10.1556/018.67.2016.4.10

Csepregi R, Temesfői V, Das S et al (2020) Cytotoxic, antimicrobial, antioxidant properties and effects on cell migration of phenolic compounds of selected transylvanian medicinal plants. Antioxidants 9:1-29. https://doi.org/10.3390/antiox9020166 
Deng J, Xu Z, Xiang C et al (2017) Comparative evaluation of maceration and ultrasonic-assisted extraction of phenolic compounds from fresh olives. Ultrason Sonochem 37:328-334. https://doi. org/10.1016/j.ultsonch.2017.01.023

Dinis T, Victor M, Leonor A (1994) Action of phenolic derivatives (Acetaminophen). Arch Biochem Biophys 315:161-169

Do QD, Angkawijaya AE, Tran-Nguyen PL et al (2014) Effect of extraction solvent on total phenol content, total flavonoid content, and antioxidant activity of Limnophila aromatica. J Food Drug Anal 22:296-302. https://doi.org/10.1016/j.jfda.2013.11.001

Fagorzi C, Checcucci A, Dicenzo GC et al (2018) Harnessing rhizobia to improve heavy-metal phytoremediation by legumes. Genes (basel). https://doi.org/10.3390/genes9110542

Fan XJ, Liu SZ, Li HH et al (2019) Effects of Portulaca oleracea L. extract on lipid oxidation and color of pork meat during refrigerated storage. Meat Sci 147:82-90. https://doi.org/10.1016/j.meats ci.2018.08.022

Gabriela G, Minna H, María Pilar A (2016) Stability of O/W emulsions packed with PLA film with incorporated rosemary and thyme. Eur Food Res Technol. https://doi.org/10.1007/s00217-016-2829-3

Generali IM, Skroza D, Ljubenkov I et al (2019) Antioxidant and antimicrobial potential of phenolic metabolites from traditionally used mediterranean. Foods 8:16

Godevac D, Zdunić G, Šavikin K et al (2008) Antioxidant activity of nine Fabaceae species growing in Serbia and Montenegro. Fitoterapia 79:185-187. https://doi.org/10.1016/j.fitote.2007.10.001

Gorlenko CL, Kiselev HY, Budanova EV et al (2020) Plant secondary metabolites in the battle of drugs and drug-resistant bacteria: new heroes or worse clones of antibiotics? Antibiotics. https://doi.org/ 10.3390/antibiotics 9040170

Halabalaki M, Urbain A, Paschali A et al (2011) Quercetin and kaempferol 3-O-[ $\alpha$-L-rhamnopyranosyl- $(\rightarrow 2)-\alpha-L$-arabinopyranoside]-7$\mathrm{O}-\alpha$-L-rhamnopyranosides from Anthyllis hermanniae: structure determination and conformational studies. J Nat Prod 74:19391945. https://doi.org/10.1021/np200444n

Halla N, Fernandes IP, Heleno SA et al (2018) Cosmetics preservation: a review on present strategies. Molecules 23:1-41. https://doi.org/ 10.3390/molecules23071571

Jones EM, Turrill W (1933) Studies in variation of Anthyllis vulneraria. J Genet 27:261-285

Julkunen-Tiitto R (1985) Phenolic constituents in the leaves of northern Willows: methods for the analysis of certain phenolics. J Agric Food Chem 33:448

Karppanen H (1991) Minerals and blood pressure. Ann Med 23:299_ 305. https://doi.org/10.3109/07853899109148064

Karthik C, Elangovan N, Kumar TS et al (2017) Characterization of multifarious plant growth promoting traits of rhizobacterial strain AR6 under Chromium(VI) stress. Microbiol Res 204:65-71. https://doi.org/10.1016/j.micres.2017.07.008

Khaw KY, Parat MO, Shaw PN, Falconer JR (2017) Solvent supercritical fluid technologies to extract bioactive compounds from natural sources: a review. Molecules. https://doi.org/10.3390/molecules2 2071186

Ksouri R, Megdiche W, Falleh H et al (2008) Influence of biological, environmental and technical factors on phenolic content and antioxidant activities of Tunisian halophytes. Comptes Rendus Biol 331:865-873. https://doi.org/10.1016/j.crvi.2008.07.024

Lahue R (1981) Spectrophotometry and fluorometry. In: Lahue R (ed) Methods in neurobiology. Springer US, Boston, pp 339-423

Larsson EH, Bornman JF, Asp H (1998) Influence of UV-B radiation and $\mathrm{Cd}^{2+}$ on chlorophyll fluorescence, growth and nutrient content in Brassica napus. J Exp Bot 49:1031-1039. https://doi.org/10. 1093/jxb/49.323.1031

Leung FY (1998) Trace elements that act as antioxidants in parenteral micronutrition. J Nutr Biochem 9:304-307. https://doi.org/10. 1016/S0955-2863(98)00018-7
Lin D, Xiao M, Zhao J et al (2016) An overview of plant phenolic compounds and their importance in human nutrition and management of type 2 diabetes. Molecules. https://doi.org/10.3390/ molecules21101374

Liu W, Yin D, Li N et al (2016) Influence of environmental factors on the active substance production and antioxidant activity in Potentilla fruticosa $\mathrm{L}$. and its quality assessment. Sci Rep 6:1-18. https://doi.org/10.1038/srep28591

Lushchak VI (2014) Free radicals, reactive oxygen species, oxidative stress and its classification. Chem Biol Interact 224:164-175. https://doi.org/10.1016/j.cbi.2014.10.016

Ma Y, Prasad MNV, Rajkumar M, Freitas H (2011) Plant growth promoting rhizobacteria and endophytes accelerate phytoremediation of metalliferous soils. Biotechnol Adv 29:248-258. https://doi.org/10.1016/j.biotechadv.2010.12.001

Maddox CE, Laur LM, Tian L (2010) Antibacterial activity of phenolic compounds against the phytopathogen Xylella fastidiosa. Curr Microbiol 60:53-58. https://doi.org/10.1007/ s00284-009-9501-0

Majdoub N, el-Guendouz S, Rezgui M et al (2017) Growth, photosynthetic pigments, phenolic content and biological activities of Foeniculum vulgare Mill., Anethum graveolens L and Pimpinella anisum L. (Apiaceae) in response to zinc. Ind Crops Prod 109:627-636. https://doi.org/10.1016/j.indcrop.2017.09.012

Manandhar S, Luitel S, Dahal RK (2019) In vitro antimicrobial activity of some medicinal plants against human pathogenic bacteria. J Trop Med. https://doi.org/10.1155/2019/1895340

Martin KR, Apple CL (2009) Polyphenols as dietary supplements: a double-edged sword. Nutr Diet Suppl. https://doi.org/10.2147/ nds.s6422

Menković N, Šavikin K, Tasić S et al (2011) Ethnobotanical study on traditional uses of wild medicinal plants in Prokletije Mountains (Montenegro). J Ethnopharmacol 133:97-107. https://doi.org/10. 1016/j.jep.2010.09.008

Mohamad R, Maynaud G, Le Quéré A et al (2017) Ancient heavy metal contamination in soils as a driver of tolerant Anthyllis vulneraria rhizobial communities. Appl Environ Microbiol 83:1-13. https:// doi.org/10.1128/AEM.01735-16

Moradi MT, Karimi A, Alidadi S, Hashemi L (2018) In vitro anti-herpes simplex virus activity, antioxidant potential and total phenolic compounds of selected iranian medicinal plant extracts. Indian J Tradit Knowl 17:255-262

Nartowska J, Wawer I, Strzelecka H (2001) Triterpenoid sapogenin from Anthyllis vulneraria L. Acta Pol Pharm - Drug Res 58:289-291

Ncube B, Finnie JF, Van Staden J (2012) Quality from the field: the impact of environmental factors as quality determinants in medicinal plants. S Afr J Bot 82:11-20. https://doi.org/10.1016/j.sajb. 2012.05.009

Neubauer U, Nowack B, Furrer G, Schulin R (2000) Heavy metal sorption on clay minerals affected by the siderophore desferrioxamine B. Environ Sci Technol 34:2749-2755. https://doi.org/10.1021/ es990495w

Osman MF, Hassan NM, Khatib A, Tolos SM (2018) Antioxidant activities of Dialium indum L. Fruit and gas chromatographymass spectrometry (GC-MS) of the active fractions. Antioxidants 7:154. https://doi.org/10.3390/antiox7110154

Osorio-Tobón JF (2020) Recent advances and comparisons of conventional and alternative extraction techniques of phenolic compounds. J Food Sci Technol 57:4299-4315. https://doi.org/10. 1007/s13197-020-04433-2

Pallardy SG (2007) Nutrients and effects. Physiol Woody Plants. https://doi.org/10.1016/B978-0-12-088765-1.50011-7

Pandey KB, Rizvi SI (2009) Plant polyphenols as dietary antioxidants in human health and disease. Oxid Med Cell Longev 2:270-278. https://doi.org/10.4161/oxim.2.5.9498 
Pisoschi AM, Pop A (2015) The role of antioxidants in the chemistry of oxidative stress: a review. Eur J Med Chem 97:55-74. https:// doi.org/10.1016/j.ejmech.2015.04.040

Prasad AS (2014) Zinc is an antioxidant and anti-inflammatory agent: its role in human health. Front Nutr 1:1-10. https://doi.org/10. 3389/fnut.2014.00014

Qiu GH, Xie X, Xu F et al (2014) Distinctive pharmacological differences between liver cancer cell lines HepG2 and Hep3B. Cytotechnology 67:1-12. https://doi.org/10.1007/s10616-014-9761-9

Rezgui M, Majdoub N, Ben-Kaab S et al (2017) How salt stress represses the biosynthesis of marrubiin and disturbs the antioxidant activity of Marrubium vulgare L. Polish J Environ Stud 26:267-277. https://doi.org/10.15244/pjoes/64792

Rouached H, Tran LSP (2015) Regulation of plant mineral nutrition: transport, sensing and signaling. Int J Mol Sci 16:29717-29719. https://doi.org/10.3390/ijms161226198

Roughead ZK, Johnson LK, Hunt JR (1999) Dietary copper primarily affects antioxidant capacity and dietary iron mainly affects iron status in a surface response study of female rats fed varying concentrations of iron, zinc and copper. J Nutr 129:1368-1376. https://doi.org/10.1093/jn/129.7.1368

Ruch RJ, Cheng S, jun, Klaunig JE, (1989) Prevention of cytotoxicity and inhibition of intercellular communication by antioxidant catechins isolated from chinese green tea. Carcinogenesis 10:10031008. https://doi.org/10.1093/carcin/10.6.1003

Ryan-harshman M, Aldoori W (2005) Food for thought health benefits of selected minerals. Can Fam Physician 51:673-675

Safdar MN, Kausar T, Nadeem M (2017) Comparison of ultrasound and maceration techniques for the extraction of polyphenols from the mango peel. J Food Process Preserv. https://doi.org/10.1111/ jfpp. 13028

Sales de Oliveira V, Augusta IM, da Conceicao Braz MV et al (2020) Aroeira fruit (Schinus terebinthifolius Raddi) as a natural antioxidant: chemical constituents, bioactive compounds and in vitro and in vivo antioxidant capacity. Food Chem 315:126274. https://doi. org/10.1016/j.foodchem.2020.126274

Sampaio BL, Bara MTF, Ferri PH et al (2011) Influence of environmental factors on the concentration of phenolic compounds in leaves of Lafoensia pacari. Braz J Pharmacogn 21:1127-1137. https://doi.org/10.1590/S0102-695X2011005000177

Segovia Gómez F, Almajano Pablos MP (2016) Pineapple waste extract for preventing oxidation in model food systems. J Food Sci 81:C1622-C1628. https://doi.org/10.1111/1750-3841.13341

Sharma S, Vig AP (2014) Preliminary phytochemical screening and in vitro antioxidant activities of Parkinsonia aculeata linn. Biomed Res Int. https://doi.org/10.1155/2014/756184
Singleton VL, Rossi JA Jr (1965) Colorimetry of total phenolics with acid reagents. Am J Enol Vitic 16:144-158

Skowyra M, Gallego MG, Segovia F, Almajano MP (2014) Antioxidant properties of Artemisia annиa extracts in model food emulsions. Antioxidants 3:116-128. https://doi.org/10.3390/antiox3010116

Stagos D (2020) Antioxidant activity of polyphenolic plant extracts. Antioxidants. https://doi.org/10.3390/antiox9010019

Suganda AG, Amoros M, Girre L, Fauconnier B (1983) Effets inhibiteurs de quelques extraits bruts et semi purifies de plantes indigenes francaises sur la multiplication de l'herpesvirus humain 1 et du poliovirus humain 2 en culture cellulaire. J Nat Prod 46:626-632

Sujkowska-Rybkowska M, Ważny R (2018) Metal resistant rhizobia and ultrastructure of Anthyllis vulneraria nodules from zinc and lead contaminated tailing in Poland. Int J Phytoremediation 20:709-720. https://doi.org/10.1080/15226514.2017.1413336

Sujkowska-Rybkowska M, Banasiewicz J, Rekosz-Burlaga H, Stępkowski T (2020) Anthyllis vulneraria and Lotus corniculatus on calamine heaps form nodules with Bradyrhizobium liaoningense-related strains harboring novel in Europe symbiotic nifD haplotypes. Appl Soil Ecol. https://doi.org/10.1016/j.apsoil.2020. 103539

Villasante J, Girbal M, Metón I, Almajano MP (2019) Effects of pecan nut (Carya illinoiensis) and roselle flower (Hibiscus sabdariffa) as antioxidant and antimicrobial agents for sardines (Sardina pilchardus). Molecules. https://doi.org/10.3390/molecules24010085

Wang T, Jónsdóttir R, Ólafsdóttir G (2009) Total phenolic compounds, radical scavenging and metal chelation of extracts from Icelandic seaweeds. Food Chem 116:240-248. https://doi.org/10.1016/j. foodchem.2009.02.041

Yang L, Wen KS, Ruan X et al (2018) Response of plant secondary metabolites to environmental factors. Molecules 23:1-26. https:// doi.org/10.3390/molecules23040762

Zengin G, Uysal S, Ceylan R, Aktumsek A (2015) Phenolic constituent, antioxidative and tyrosinase inhibitory activity of Ornithogalum narbonense L. from Turkey: a phytochemical study. Ind Crops Prod 70:1-6. https://doi.org/10.1016/j.indcrop.2015.03.012

Publisher's Note Springer Nature remains neutral with regard to jurisdictional claims in published maps and institutional affiliations. 